Volume 4 Issue 1, March 2019: pp. 1-10. Copyright @ LamLaj. Faculty of Law, Lambung Mangkurat University, Banjarmasin, South Kalimantan, Indonesia. ISSN: 2502-3136 | e-ISSN: 2502-3128. Open Access at: http://lamlaj.ulm.ac.id/web/

\title{
ASAS INDISSOLUBILITY DALAM HUKUM PERKAWINAN KANONIK
}

\author{
Franky Anggriawan', Djoni S. Gozali², Rachmadi Usman ${ }^{3}$
}

\author{
Program Magister Kenotariatan Fakultas Hukum Universitas Lambung Mangkurat. \\ Jl.Brigjend H.Hasan Basri Banjarmasin 70123 Indonesia Fax: 05114321658 \\ +E-mail :frankgatreas@gmail.com \\ Fakultas Hukum Universitas Lambung Mangkurat. \\ Jl.Brigjend H.Hasan Basri Banjarmasin 70123 Indonesia \\ Fax:05114321658+E-mail :djoni.sh.mh@gmail.com \\ Fakultas Hukum Universitas Lambung Mangkurat. \\ Jl.Brigjend H.Hasan Basri Banjarmasin 70123 Indonesia. \\ Fax:05114321658+E-mail: usmanrachmadiu@gmail.com
}

Submitted : 12/02/2019 Reviewed 29/03/2019 Accepted:31/03/2019

\begin{abstract}
The aim of this reseach are to study was to find out the existence of the principle of indissolubility in canonical law and the national marriage law against court decisions that cut Catholic marriage; and to find out the legal position of a husband and wife who are Catholic after a court ruling due to divorce. This type of normative legal research is legal research conducted by examining and using legal materials, namely primary legal materials, secondary legal materials and tertiary legal materials obtained from library research. According to the results of the study that the court did not consider and did not interpret the provisions of Catholic religious law
\end{abstract}

Keywords: Indissolubility Principle; Canonical Book; Catholic Marriage Divorce

\begin{abstract}
Abstrak: Tujuan penelitian adalah untuk mengetahui eksistensi asas indissolubility dalam hukum kanonik dan hukum perkawinan nasional terhadap putusan pengadilan yang memutus perkawinan katolik; dan untuk mengetahui kedudukan hukum suami istri yang beragama katolik setelah putusan pengadilan akibat perceraian. Jenis penelitian hukum normatif merupakan penelitian hukum yang dilakukan dengan cara meneliti dan menggunakan bahan hukum yaitu bahan hukum primer, bahan hukum sekunder dan bahan hukum tersier yang didapat dari penelitian kepustakaan (library research). Menurut hasil penelitian bahwa pengadilan tidak mempertimbangkan serta tidak memaknai ketentuan hukum agama Katolik.
\end{abstract}

Kata Kunci: Asas Indissolubility; Kitab Kanonik; Perceraian Perkawinan Katolik 


\section{PENDUHULUAN}

Perkawinan adalah sebuah jalinan hubungan yang sakral bagi sepasang kekasih. Dalam Undang-Undang Nomor 1 Tahun 1974 tentang Perkawinan Pasal 2 ayat 1 mengatakan bahwa perkawinan itu sah menurut agama dan kepercayaannya masing-masing. Hal ini merupakan salah satu wujud aturan tata tertib pernikahan yang dimiliki oleh negara Indonesia sebagai bangsa yang berdaulat agar terjaminnya ketertiban pranata pernikahan dalam masyarakat, maka Undang-Undang Perkawinan, menentukan bahwa setiap perkawinan harus dicatat oleh petugas yang berwenang. Didalam konteks umat atau penduduk atau warga negara beragama Katolik diaturlah perkawinan itu didalam kitab hukum kanonik yang tertuang dalam Pasal Kanon 1055 sampai Kanon 1160 sekian secara khusus yang mengatur mengenai asas indissolubility diatur dalam Kanon 1141, oleh karena itu mengapa Negara justru mengabulkan permohonan perceraian melalui putusan pengadilan sementara prinsip tak terceraikan dalam perkawinan menurut Hukum Kanonik adalah jelas bahwa hidup perkawinan tidak bisa diceraikan oleh kuasa manusiawi manapun dan dengan alasan apapun karena perkawinan Katolik adalah perkawinan sakramental yang berprinsip tak terceraikan; institusi ini lahir sebagai sarana keselamatan Allah bagi manusia sekaligus sarana penciptaan Allah dalam kehidupan manusia. Melalui keluarga, Allah menciptakan manusia-manusia baru untuk melanjutkan karya keselamatan-Nya di muka bumi ini.

Penegasan ini (perkawinan tak terceraikan) memperoleh dasar yuridisnya dalam ajaran gereja Katolik pada Kanon 1055 dan 1056 serta Kanon 1141. "Tak terceraikan" atau indissolubilitas adalah perkawinan yang telah dilangsungkan secara sah menurut tuntutan hukum, mempunyai akibat tetap dan tidak dapat diceraikan atau diputuskan oleh kuasa manapun kecuali oleh kematian. Sifat tak terceraikan (indissolubilitas) perkawinan Katolik dibedakan menjadi dua, yakni: Indissolubilitas absoluta: yaitu jika ikatan perkawinan tidak dapat diputuskan oleh kuasa manapun kecuali oleh kematian satu-satunya perkawinan yang memiliki indissolubilitas absoluta adalah perkawinan sakramen yang sudah disempurnakan dengan persetubuhan (ratum et consummatum), sebagaimana dikatakan dalam Kanon 1141. Sebagaimana Kristus selalu setia dan tidak pernah meninggalkan gereja-Nya demikian juga antara suami-isteri yang telah dibaptis tidak dapat saling memisahkan diri (bdk. Ef. 5 ayat 22-33).

Dalam Undang-undang Nasional Nomor 1 Tahun 1974 tentang Perkawinan, merupakan salah satu wujud aturan tata tertib pernikahan yang dimiliki oleh negara Indonesia sebagai bangsa yang berdaulat, di samping aturan-aturan tata tertib pernikahan yang lain yaitu Hukum Adat dan Hukum Agama, Agar terjaminnya ketertiban pranata pernikahan dalam masyarakat, maka Undang-Undang Perkawinan, menentukan bahwa setiap perkawinan harus dicatat oleh petugas yang berwenang.

Sedangkan Perkawinan Katolik itu pada dasarnya berciri satu untuk selamanya dan tak terceraikan. Kita menyebutnya sifat $\mathrm{Mo}$ nogam dan Indissolubile. Monogam berarti satu laki-laki dengan satu perempuan, sedang indissolubile berarti, setelah terjadi perkawinan antara orang-orang yang dibaptis ( $r a-$ tum) secara sah dan disempurnakan dengan persetubuhan, maka perkawinan menjadi tak terceraikan, kecuali oleh kematian. Ini dapat ditemukan dalam Hukum Gereja tahun 1983 
(Kanon 1141). Pada dasarnya agama Katolik menentang adanya perceraian. Namun, secara hukum negara, di Indonesia diatur bahwa perceraian hanya dapat dilakukan di depan Sidang Pengadilan setelah Pengadilan yang bersangkutan berusaha dan tidak berhasil mendamaikan kedua belah pihak dan untuk melakukan perceraian harus ada cukup alasan, bahwa antara suami isteri itu tidak akan dapat hidup rukun sebagai suami isteri (lihat Pasal 39 ayat [1] dan ayat [2] jo Pasal 2 Undang-Undang Perkawinan). Mengenai alasan-alasan perceraian dapat dilihat dalam Penjelasan Pasal 39 ayat (2) Undang-Undang Perkawinan yaitu: ${ }^{1}$

a. Salah satu pihak berbuat zina atau menjadi pemabuk, pemadat, penjudi dan lain sebagainya yang sukar disembuhkan;

b. Salah satu pihak meninggalkan yang lain selama 2 (dua) tahun berturut- turut tanpa izin pihak yang lain dan tanpa alasan yang sah atau karena hal lain di luar kemauannya;

c. Salah satu pihak mendapat hukuman penjara 5 (lima) tahun atau hukuman yang lebih berat setelah perkawinan berlangsung;

d. Salah satu pihak melakukan kekejaman atau penganiayaan berat yang membahayakan terhadap pihak yang lain;

e. Salah satu pihak mendapat cacat badan atau penyakit yang mengakibatkan tidak dapat menjalankan kewajibannya sebagai suami/isteri;

f. Antara suami dan isteri terus menerus terjadi perselisihan dan pertengkaran dan tidak ada harapan akan hidup rukun lagi dalam rumah-tangga.

Dalam praktik, permohonan cerai secara

1 Hasbullah. 1981. Kumpulan Lengkap Undangundang dan Peraturan Perkawinan-Indonesia. Jakarta Pusat: Penerbit Djambatan, hlm 13.
Katolik jarang sekali dikabulkan. Tapi, pasangan tersebut tetap dapat bercerai secara perdata, walaupun secara Katolik perceraian tersebut dianggap tidak sah. Walaupun Hukum Katolik menentang adanya perceraian, namun dalam Katolik dikenal adanya prosedur pembatalan perkawinan (anulasi). Akibat hukum dari pembatalan perkawinan menurut hukum gereja adalah kedua pihak yang telah dibatalkan perkawinannya dapat menikah lagi.

Gereja Katolik tidak mengakui efektifitas putusan cerai dari pengadilan sipil, artinya sekalipun secara de facto pasangan Katolik tersebut sudah cerai melalui putusan pengadilan sipil, mereka masih terikat oleh ikatan perkawinan gerejawi. Penulis mengangkat permasalahan perceraian perkawinan Katolik berdasarkan Hukum Agama Katolik. Pilihan tema ini dilatarbelakangi oleh adanya putusan Pengadilan Negeri Marabahan Nomor: 03/Pdt.G/2011/PN.Mrb yang memutus suatu ikatan Perkawinan Katolik dengan putusan perceraian serta adanya Putusan Pengadilan Tinggi Kalimantan Selatan Nomor: 05/ PDT./2012/PT.BJM yang menguatkan putusan perceraian sebelumnya pada Pengadilan Negeri Marabahan.

Padahal jelas adanya Yurisprudensi Mahkamah Agung No. Reg. No 1400 K/ Pdt/1986 tanggal 20 Januari 1989 dalam perkara yang sama yaitu perceraian agama katolik, yang berbunyi: "Undang-Undang Perkawinan menganut asas bahwa perkawinan adalah sah apabila dilakukan menurut hukum masing-masing agamanya dan kepercayaannya dan itu merupakan salah satu perwujudan dari Pancasila sebagai Falsafah Negara. Perkawinan tidak lagi dilihat hanya dengan hubungan perdata, sebab perkawinan mempunyai hubungan erat sekali dengan aga$\mathrm{ma} /$ kerohanian, sehingga tidak ada perkawi- 
nan di luar hukum masing-masing agamanya dan kepercayaannya. Artinya Tergugat/Pembanding/Pemohon Kasasi dan Penggugat/Terbanding/Termohon Kasasi dalam perkara perceraian khususnya agama katolik tetap terikat pada Hukum Agama Katolik.

Setiap perkawinan Katolik memiliki asas Indissolubility yang tidak memungkinkan adanya perceraian.

\section{METODE}

\section{Jenis Penelitian}

Penelitian ini menggunakan jenis penelitian hukum normatif, yaitu merupakan penelitian hukum yang dilakukan dengan cara meneliti dan menggunakan bahan hukum yaitu bahan hukum primer, bahan hukum sekunder dan bahan hukum tersier yang didapat dari penelitian kepustakaan (library research). Peter Mahmud Marzuki menjelaskan penelitian hukum normatif adalah: "Suatu proses untuk menemukan suatu aturan hukum, prinsipprinsip hukum, maupun doktrin-doktrin hukum untuk menjawab permasalahan hukum yang dihadapi. Penelitian hukum normatif dilakukan untuk menghasilkan argumentasi, teori atau konsep baru sebagai preskripsi dalam menyelesaikan masalah yang sedang dihadapi". 13

\section{Tipe Penelitian}

Tipe penelitian "Doctrinal Research" yaitu secara sistematisasi mengkoreksi dan memperjelas suatu aturan hukum yang berlaku pada bidang hukum tertentu dengan cara melakukan analisis terhadap teks yang bersifat autoritatif yang meliputi bahan hukum primer dan sekunder. ${ }^{2}$ Dalam hal ini penulis menganalisis tentang ketentuan dalam hal Perkawinan

2 Peter Mahmud Marzuki. 2005. Penelitian Hukum. Jakarta: Kencana, hlm. 35. menurut Undang-Undang Perkawinan dan Perkawinan dalam Kitab Hukum Kanonik (Codex Juris Canonici) serta Putusan Pengadilan Negeri. Di mana terdapat konflik norma tentang aturan perkawinan yang tertuang dalam sebuah kitab dengan aturan perkawinan yang tertuang dalam undang-undang.

\section{Sifat Penelitian}

Penelitian ini bersifat preskriftif analisis yaitu mempelajari tujuan hukum, nilai-nilai keadilan, validitas aturan hukum, konsep-konsep hukum dan norma-norma hukum. Penelitian akan mengkritisi serta memberikan solusi hukum atas permasalahan yang dikaji dan dianalisa dalam penelitian hukum ini. Penelitian ini bersifat preskriptif analitis yaitu penelitian yang bersifat secara ilmiah dengan suatu metode yang bertujuan untuk mempelajari satu atau beberapa gejala dengan jalan menganalisanya dan dengan mengadakan pemeriksaan yang mendalam terhadap fakta tersebut untuk kemudian mengusahakan suatu pemecahan masalah-masalah yang ditimbulkan oleh fakta tersebut. ${ }^{3}$

\section{Pendekatan Penelitian}

Pendekatan penelitian ini adalah pendekatan perundang-undangan (statute apporach) dan pendekatan kasus. Statue Approach (Pendekatan Undang-Undang), yaitu pendekatan yang menelaah semua UndangUndang dan regulasi yang berhubungan dengan isu hukum, menelaah konsistensi dan kesesuaian antara satu Undang-Undang dengan Undang-Undang lainnya atau dengan Undang-Undang Dasar, mencari "ratio legis" dan dasar ontologis perundang-undangan. Pendekatan ini harus menginventarisir semua Undang-Undang terkait dengan isu hukum. Peneliti melakukan pendekatan terhadap

$3 \quad$ Ibid. hlm.143 
Undang-Undang Perkawinan dan Peraturan Agama yang tertuang dalam Kitab Hukum Kanonik. Pendekatan kasus dilakukan untuk menganalisa putusan pengadilan yang ada.

Studi Kasus yaitu pendekatan penelitian yang dilakukan secara mendalam terhadap suatu keadaan dengan menggunakan cara-cara sistematis dalam melakukan pengamatan, pengumpulan data dan analisis informasi. Dalam penelitian ini terkait dengan konsep Putusan Pengadilan terhadap perceraian perkawinan. Peneliti mencoba menelaah kejelasan konsep dalam hal putusan perceraian yang diputus oleh Pengadilan Negeri.

\section{ANALISIS DAN PEMBAHASAN}

Eksistensi Asas Indissolubility Dalam Hukum Kanonik Dan Hukum Perkawinan Nasional Terhadap Putusan Pengadilan Yang Memutus Perkawinan Katolik

\section{Hakikat Asas Indissolubility dalam Hukum Kanonik}

Hukum gereja sebagai salah satu studi teologi yang secara sistematis mengkaji prinsip-prinsip ekklesiologis dari aturan-aturan dalam gereja memampukan gereja untuk menyusun aturan sesuai dengan hekekat dirinya. Pengenalan diri yang baik memampukan gereja untuk tidak dengan mudah untuk mengambil alih aturan-aturan pemerintahan atau lembaga lainnya untuk menyusun aturan gereja. Gereja tidak hadir karena dirinya dan oleh dirinya. Gereja hadir sebagai karya Allah Tritungal yang berlandaskan Asas Indissolubility (Tak Terpisahkan) untuk menjalankan misi Allah Tritunggal. Dalam kesadaran ini gereja menata dirinya sehingga mampu melayani sesuai dengan hakikat dirinya. Dari sudut pandang ini terlihat bahwa adanya aturan dalam gereja merupakan sebuah komitmen iman gereja untuk menata diri dan melayani sesuai hakikat dirinya. ${ }^{4}$

\section{Eksistensi Perceraian dalam Hukum Perkawinan Nasional}

Undang-Undang Perkawinan harus dipahami sebagai Undang-Undang Nasional yang keseluruhannya merupakan satu kesatuan yang bulat. Undang-Undang Perkawinan merupakan satu kesatuan Undang-Undang dan satu kesatuan sistem hukum yang babbab, pasal-pasal dan ayat-ayatnya tidak boleh ditafsirkan bertentangan satu sama lain. Sesuai dengan sejarahnya, pemahaman dan penafsiran Undang-Undang Perkawinan tidak boleh dipertentangkan dengan hukum agama, khususnya hukum Islam. Bahkan mempelajari Undang-Undang Perkawinan harus mempunyai latar belakang dan dasar pemahaman terhadap hukum Islam, sebab dalam banyak ketentuannya adalah ajaran/hukum Islam, memahami Undang-Undang Perkawinan dan penafsirannya harus bertumpu pada pandangan wawasan nusantara, artinya UndangUndang Perkawinan sebagai hukum nasional hendaknya dipahami dan dilaksanakan di seluruh wilayah Republik Indonesia yang merupakan satu kesatuan wilayah hukum. Undang-Undang Perkawinan adalah mewujudkan hukum nasional yang baru berdasarkan Pancasila, yang merupakan norma-norma hukum yang berwawasan nusantara, karena itu, dalam pemahaman bab-bab, pasal-pasal dan ayat-ayatnya harus disesuaikan dengan semangat menggantikan ketentuan-ketentuan hukum yang diskriminatif yang diciptakan oleh Pemerintah Belanda. Undang-Undang Perkawinan merupakan norma hukum nasi-

4 Rubiyatmako Robertus 2011. Perkawinan Katolik Menurut Kitab Hukum Kanonik. Yogyakarta, diakses tanggal 7 Juli 2018 
onal di dalam peningkatan pergaulan hidup internasional bangsa dan negara Indonesia. Karenanya, di dalamnya diatur perkawinan di luar dan perkawinan Campuran. Disadari bahwa sesuai dengan asas Bhinneka Tunggal Ika, maka ada perbedaan fundamental antara warga negara Indonesia di dalam hukum. Undang-Undang Perkawinan adalah hukum nasional Indonesia di dalam pergaulan Internasional yang bertatanan hukum internasional. Karena dalam Undang-Undang Perkawinan ada beberapa pasal yang berhubungan dan berkaitan dengan hukum perdata internasional maka harus dipahami dalam konteks hukum internasional privat (Hukum Perdata Internasional).

\section{Asas Perkawinan}

Dalam Undang-Undang Perkawinan ditentukan prinsip atau asas-asas mengenai perkawinan yang telah disesuaikan dengan perkembangan dan tuntutan zaman. Prinsip atau asas-asas yang tercantum dalam UndangUndang Perkawinan adalah sebagai berikut:

a. Asas perkawinan kekal. Setiap perkawinan bertujuan untuk membentuk keluarga yang bahagia dan kekal. Artinya, perkawinan hendak seumur hidup. Hanya dengan perkawinan kekal saja dapat membentuk keluarga yang bahagia dan sejahtera. Prinsip perkawinan kekal ini dapat dijumpai dalam Pasal 1 UndangUndang Perkawinan yang menyatakan, bahwa: "Perkawinan ialah ikatan lahir batin antara seorang pria dengan seorang wanita sebagai suami istri dengan tujuan membentuk keluarga (rumah tangga) yang bahagia dan kekal berdasarkan Ketuhanan Yang Maha Esa.”

b. Asas perkawinan menurut hukum agama atau kepercayaan agamanya. Perkawinan hanya sah bilamana dilakukan menurut hukum masing-masing agamanya dan kepercayaannya. Artinya, perkawinan akan dianggap sah bilamana perkawinan itu dilakukan menurut hukum agama atau kepercayaan agama yang dianut oleh calon mempelai. Prinsip ini dapat dijumpai dalam Pasal 2 ayat (1) UndangUndang Perkawinan yang menentukan, bahwa perkawinan adalah sah, apabila dilakukan menurut hukum masing-masing agamanya dan kepercayaannya itu.

c. Asas perkawinan terdaftar. Tiap-tiap perkawinan yang dilakukan menurut hukum masing-masing agamanya dan kepercayaannya itu akan dianggap mempunyai kekuatan hukum bilamana dicatat menurut peraturan perundang-undangan yang berlaku. Perkawinan yang tidak dicatat tidak mempunyai kekuatan hukum menurut Undang-Undang Perkawinan. Prinsip ini ditegaskan dalam Pasal 2 ayat (2) Undang-Undang Perkawinan yang menentukan, bahwa tiap-tiap perkawinan dicatat menurut peraturan perundang-undangan yang berlaku.

d. Asas perkawinan monogami. UndangUndang Perkawinan menganut asas monogami, bahwa pada asasnya dalam suatu perkawinan seorang pria hanya boleh mempunyai seorang istri, seorang wanita hanya boleh mempunyai seorang suami dalam waktu yang bersamaan. Artinya, dalam waktu yang bersamaan, seorang suami atau istri dilarang untuk menikah dengan wanita atau pria lain. Prinsip ini ditegaskan dalam Pasal 3 ayat (1) Undang-Undang Perkawinan yang menyatakan bahwa pada asasnya dalam suatu perkawinan seorang pria hanya boleh mempunyai seorang istri. Seorang 
wanita hanya boleh mempunyai seorang suami.

\section{Dasar Perkawinan Tak Terceraikan Dalam Kitab Hukum Kanonik}

Perkawinan tak terceraikan adalah perkawinan yang tidak bisa diceraikan atau diputuskan dengan alasan yang secara kuat legitim. Konsep perkawinan tak terceraikan ini banyak dijumpai dalam literatur perkawinan menurut agama Katolik. Di agama lain (non Katolik) konsep ini ada namun tidak diatur secara tegas mengenai tak terceraikannya sebuah institusi perkawinan. Dasar sifat tak terceraikannya perkawinan Katolik adalah: Kitab Suci (Markus 10:2-12; Matius 5:31-32; 19:2-12; Lukas 6:18); Ajaran Gereja (Misalnya) Konsili Vatikan II (GS 48), Familiaris Concortio 20, dan Katekismus Gereja Katolik 1644-1645; dan Kitab Hukum Kanonik. Dasar konsep perkawinan tak terceraikan ini adalah konsep perkawinan sebagai sakramen sebagaimana dikatakan dalam Kanon 1055 ayat (1) sebagai berikut:

"Dengan perjanjian perkawinan pria dan wanita membentuk antara mereka kebersamaan seluruh hidup; dari sifat kodratinya, perjanjian itu terarah pada kesejahteraan suami-istri serta kelahiran dan pendidikan anak; oleh Kristus Tuhan. Perjanjian perkawinan antara orang-orang yang dibabtis, diangkat ke martabat sakramen."

\section{Eksistensi Asas Indisollubility dalam Putusan Pengadilan Yang Memutus Perkawinan Katolik.}

Hakikat putusan adalah sebagai sarana penyelesaian sengketa karena ketidakmampuan para pihak untuk menyelesaikan sendiri sengketa yang terjadi. Pengertian ini adalah hakikat putusan secara umum, un- tuk perceraian putusan diperlukan karena menjadi syarat putusnya perkawinan sesuai ketentuan Undang-Undang Perkawinan. Putusan Pengadilan Negeri Marabahan Nomor .03/Pdt.G/2011/ON.Mrb adalah putusan perceraian namun yang lebih disorot adalah fakta hukum dalam pertimbangan hukum hakim yaitu tentang pertimbangan hukum Undang-Undang Perkawinan dan Kitab Hukum Kanonik.

Mengemukakan tiga hal yang dapat mengakibatkan terputusnya suatu perkawinan yaitu kematian, perceraian dan atas keputusan pengadilan. Jika perceraian terjadi akibat kematian maka akan putus dengan sendirinya karena hal tersebut diluar kuasa manusia untuk menghindarinya. Putusnya perkawinan karena perceraian dan putusan pengadilan diatur secara ketat demi kekekalan perkawinan. Norma dalam Katolik sebenarnya menentang keras adanya perceraian, ini bisa dilihat dalam Alkitab "Apa yang telah dipersatukan Allah, tidak boleh diceraikan manusia" (Matius 19:6), dan kekuasaan hanya diberikan oleh Paus di Roma itupun bukan kuasa menceraikan melainkan hanya pembatalan perkawinan. Dalam putusan Pengadilan Negeri Marabahan Nomor.03/Pdt.G/2011/ PN.Mrb adalah upaya perceraian melalui pengadilan karena lebih memungkinkan untuk dikabulkan khususnya bagi pasangan perceraian beragama Katolik Pasal 39 UndangUndang Perkawinan mensyaratkan bahwa untuk melakukan perceraian harus terdapat cukup alasan bahwa antara suami istri tidak akan dapat hidup rukun sebagai suami istri. Undang-Undang Perkawinan sendiripun telah menentukan alasan-alasan perceraian yang dimuat dalam Pasal 19 PP No. 9 Tahun 1975 yaitu (a) Salah satu pihak melakukan zina, menjadi pemabok, pemadat, penjudi dan lain 
sebagainya yang susah disembuhkan atau dikembalikan keadaannya seperti semula; (b) salah satu pihak ditinggalkan pihak lain dan tanpa alasan yang sah atau karena hal lain di luar kemampuannya; (c) salah satu pihak mendapatkan hukuman penjara 5 tahun atau hukuman yang lebih berat setelah perkawinan berlangsung; Meninjau kesembilan point alasan perceraian dalam gugatan perkara perdata tersebut mendasarkan pada alasan perceraian sesuai Undang-Undang Perkawinan. Jika dikaitkan dengan asas kepastian pranata hukum dan kelembagaan hukum perceraian, maka disini para pihak telah meyakini bahwa perkawinan mereka dilindungi oleh undangundang karena mereka sejak awal berdasarkan pada Pasal 2 ayat (1) dan karena hakim memandang pasal tersebut berlaku fakultatif maka tidak akan mempersulit kehendak perceraian dan hakim hanya akan melanjutkan memeriksa, mengadili dan memutus perkara perceraian tersebut dengan berpedoman pada asas peradilan sebagai tanggung jawabnya atas kewenangan yang telah diberikan konstitusi. Dalam asas perlindungan Hukum yang seimbang selama dan setelah proses hukum perceraian adalah semata mata untuk mencapai tujuan hukum. Kepastian hukum dicapai dengan adanya kepastian bahwa perkawinan hanya memenuhi ketentuan Pasal 2 ayat (1) menjadikan perkawinan itu sah tanpa melihat terpenuhinya ayat lain. Keadilan hukum dipenuhi dengan menyeimbangkan kedudukan penggugat dan tergugat dengan tidak menjustifikasi salah satu pihaknya saja dan berpedoman Jika terjadi pasangan yang pasangan yang telah melakukan perkawinan yang sah menurut agama, karena itu sah pula menurut menurut Pasal 2 ayat (1) Undang-undang Perkawinan.

Berdasarkan analisis maka dengan demikian semestinya Pengadilan Negeri Marabahan tidak mengabulkan gugatan perceraian mengingat kembali Asas-asas Undang-Undang Perkawinan dan Asas-asas Kitab Hukum Kanonik (codex iuris canonici) yang tercermin pada pasal-pasalnya tersebut:

1. Asas Agama

Suatu perkawinan adalah sah apabila dilaksanakan menurut hukum masingmasing agamanya dan kepercayaannya itu. Undang-Undang Perkawinan Pasal 2 ayat (1).

2. Asas Monogami

Pada dasarnya pria hanya boleh mempunyai seorang istri; dan seorang wanita hanya boleh mempunyai seorang suami. Undang-Undang Perkawinan (psl. 3 ayat (1).

3. Asas Indissolubility

Perkawinan ratum dan disempurnakan dengan persetubuhan tidak dapat diputus oleh kuasa manusiawi mana pun juga dan atas alasan apa pun, selain oleh kematian. Kitab Hukum Kanonik (codex iuris canonici) Kanon 1141. Mengingat kembali bahwa Negara Republik Indonesia mengatakan, menunjuk bahwa sahnya suatu perkawinan ialah menurut Pasal 2 Ayat (1) berdasarkan Undang-Undang Perkawinan. Bahwa dengan adanya hal demikian maka agama Katolik mempunyai aturan khusus yang terdapat pada Kitab Hukum Kanonik pada Kan. 1141. Sehingga Pengadilan Negeri tidak semestinya mengabulkan gugatan perceraian dalam bentuk serta alasan apapun.Adapun Eksistensi (keberadaan) Asas Indissolubility (asas tidak terpisahkan) dalam ajaran agama Katolik tidak mengenal adanya perceraian hal ini didasarkan pada ajaran agama yang menyatakan bahwa 
apa yang telah dipersatukan Tuhan tidak dapat dipisahkan oleh manusia dan bahwa perkawinan adalah ikatan lahir batin antara seorang pria dengan seorang wanita sebagai suami istri dengan tujuan untuk membentuk keluarga/rumah tangga yang bahagia dan kekal berdasarkan Ketuhanan Yang Maha Esa Dan firmanNya: "Sebab itu laki-laki akan meninggalkan ayah dan ibunya dan bersatu dengan isterinya, sehingga keduanya itu menjadi satu daging. Demikianlah mereka bukan lagi dua, melainkan satu. Karena itu, apa yang telah dipersatukan Allah, tidak boleh diceraikan manusia" (Matius 19:5-6). ${ }^{5}$ Eksistensi firman ini diakui serta diyakini seluruh umat Kristen diseluruh dunia karena berdasarkan Kitab Injil. Kemudian Kristen Katolik membuat aturan khusus yang tidak lepas dari asas kitab Injil mengenai perpisahan ataupun perceraian dalam hukum gereja. Aturan tersebut terdapat pada Kitab $\mathrm{Hu}-$ kum Kanonik (codex iuris canonici) pada Kanon 1141 yang mengatakan bahwa 'Perkawinan ratum dan disempurnakan dengan persetubuhan tidak dapat diputus oleh kuasa manusiawi mana pun juga dan atas alasan apa pun, selain oleh Kematian".

Kedudukan Hukum Suami Isteri Yang Beragama Katolik Setelah Putusan Pengadilan Akibat Perceraian

\section{Hakikat Perceraian Dalam Hukum Perkawinan Nasional.}

Sebelum mengenal lebih jauh tentang perceraian maka penulis membahas ter-

5 Paus Yohanes Paulus II, Kitab Hukum Kanonik. Jakarta: Penerbit Sekretariat KWI, hlm. 322 lebih dahulu tentang pernikahan. Pernikahan adalah suatu ikatan antara pria dan wanita dewasa yang berdasarkan hukum, adat-istiadat, agama atau Undang-Undang. Menurut Undang-Undang Perkawinan pengertian pernikahan adalah ikatan lahir batin antara seorang pria dengan seorang wanita sebagai suami isteri dengan tujuan membentuk keluarga (rumah tangga) yang bahagia dan kekal berdasarkan Ketuhanan Yang Maha Esa. Pernikahan sebagai komitmen yang legal antara dua orang untuk berbagi kedekatan fisik dan emosional, berbagai macam tugas, serta sumber perekonomian. Pernikahan bukan lagi berupa seperangkat norma dan kewajiban sosial yang harus ditegakkan secara luas, tetapi merupakan hubungan sukarela dimana individu bisa menjalankan dan menghentikan sesuai keinginan. Setelah menikah, pasangan tidak hanya diharapkan menyesuaikan dengan standar perilaku tradisional, namun juga diharapkan untuk mengorbankan kepentingan pribadi, apabila perlu, demi pernikahan. Pernikahan biasanya digambarkan sebagai bersatunya dua individu, tetapi pada kenyataannya adalah persatuan dua sistem keluarga secara keseluruhan dan pembangunan sebuah sistem ketiga yang baru berdasarkan beberapa pengertian tersebut, dapat disimpulkan bahwa pengertian pernikahan adalah suatu ikatan yang sah berdasar hukum agama dan Undang-Undang yang menyatukan dua individu untuk berbagi kedekatan fisik dan emosional, berbagai macam tugas, serta sumber perekonomian dalam rangka mencapai kebahagiaan.

\section{Hakikat Perceraian dalam Pandangan} Gereja Katolik.

Pandangan mengenai perceraian, penting untuk mengingat kata-kata Alkitab dalam Maleakhi 2:16a "Sebab Aku mem- 
benci perceraian, firman TUHAN, Allah Israel." Menurut Alkitab, kehendak Allah terhadap pernikahan sebagai komitmen seumur hidup. "Demikianlah mereka bukan lagi dua, melainkan satu. Karena itu, apa yang telah dipersatukan Allah, tidak boleh diceraikan manusia" (Matius 19:6). Meskipun demikian, Allah menyadari bahwa karena pernikahan melibatkan dua manusia yang berdosa, perceraian akan terjadi. Dalam Perjanjian Lama, Allah menetapkan beberapa hukum untuk melindungi hak-hak dari orang yang bercerai, khususnya bagi perempuan (Ulangan 24:14). Yesus menekankan bahwa hukum-hukum ini diberikan karena ketegaran hati manusia, bukan karena rencana Allah (Matius 19:8). Kontroversi mengenai apakah perceraian dan pernikahan kembali diizinkan oleh Alkitab mengacu pada kata-kata Yesus dalam Matius 5:32 dan 19:9. Frasa "kecuali karena zinah," adalah satu-satunya alasan dalam Alkitab di mana Allah memberikan izin untuk perceraian dan pernikahan kembali. Banyak penafsir Alkitab yang memahami "klausul pengecualian" ini hanya merujuk pada "perzinahan" yang terjadi pada masa "pertunangan." Dalam tradisi Yahudi, pria dan perempuan dianggap sudah menikah walaupun mereka masih "bertunangan." Percabulan dalam masa "pertunangan" ini bisa menjadi satu-satunya alasan bagi seseorang untuk bercerai. Namun demikian, bahasa Yunani yang diterjemahkan sebagai "perzinahan" bisa merujuk pada bermacam bentuk percabulan. Kata ini bisa berarti perzinahan, pelacuran dan penyelewengan seks. Yesus mungkin bermaksud mengatakan bahwa perceraian diperbolehkan kalau terjadi perzinahan. Hubungan seksual merupakan bagian integral dari ikatan penikahan, "keduanya menjadi satu daging" (Kejadian 2:24; Matius 19:5; Efesus 5:31). Oleh sebab itu, memutuskan ikatan itu melalui hubungan seks di luar pernikahan dapat menjadi alasan untuk bercerai.

\section{Status Hukum Perkawinan Suami- Istri Agama Katolik Setelah Putusan Pengadilan Akibat Perceraian.}

\section{Perceraian Dalam Pandangan Kitab Hukum Kanonik.}

Perkawinan tak terceraikan adalah perkawinan yang tidak bisa diceraikan atau diputuskan dengan alasan yang secara kuat legitim. Konsep perkawinan tak terceraikan ini banyak dijumpai dalam literatur perkawinan menurut agama Katolik. Di agama lain (non Katolik) konsep ini ada namun tidak diatur secara tegas mengenai tak terceraikannya sebuah institusi perkawinan. Dasar sifat tak terceraikannya perkawinan Katolik adalah: Kitab Suci (Markus 10:2-12; Matius 5:31-32; 19:2-12; Lukas 6:18); Apa yang telah dipersatukan Allah, tidak boleh diceraikan manusia" (Mat 19:6). Hukum ini tetap berlaku, tidak hanya untuk perkawinan Katolik, tapi juga perkawinan agama lain, dan perkawinan adat. Gereja Katolik pun tidak boleh menceraikan perkawinan agama lain.

Dengan demikian dapat disimpulkan bahwa pekawinan tak teceraikan dalam pandangan ajaran gereja Katolik memperoleh dasarnya pada Kanon 1055 dan 1056 serta Kanon 1141; bahwa hidup perkawinan tidak bisa diceraikan oleh kuasa manusiawi manapun dan dengan alasan apa pun. Jika melakukan perceraian maka dianggap melakukan zinah karena perkawinan katolik adalah perkawinan sakramental; institusi ini lahir sebagai sarana keselamatan Allah bagi manusia sekaligus sarana penciptaan Allah dalam kehidupan manusia. Melalui keluarga, Allah 
menciptakan manusia-manusia baru untuk melanjutkan karya keselamatan-Nya di muka bumi ini.

\section{Perceraian Dalam Pandangan Hukum}

\section{Perkawinan Nasional.}

Undang-Undang Perkawinan tidak memberikan definisi mengenai perceraian secara khusus. Pasal 39 ayat (2) Undang-Undang Perkawinan serta penjelasannya secara kelas menyatakan bahwa perceraian dapat dilakukan apabila sesuai dengan alasan-alasan yang telah ditentukan. Definisi perceraian di Pengadilan Agama itu, dilihat dari putusnya perkawinan. Putusnya perkawinan di Undang-Undang Perkawinan dijelaskan, yaitu:

1. karena kematian

2. karena perceraian

3. karena putusnya pengadilan

Dengan demikian, perceraian merupakan salah satu sebab putusnya perceraian. Undang-Undang Perkawinan menyebutkan adanya 16 hal penyebab perceraian. Penyebab perceraian tersebut lebih dipertegas dalam rujukan Pengadilan Agama, yaitu Kompilasi Hukum Islam (KHI), dimana yang pertama adalah melanggar hak dan kewajiban. Dalam hukum Islam, hak cerai terletak pada suami. Oleh karena itu di Pengadilan Agama maupun pengadilan Negeri ada istilah Cerai Talak. Sedangkan putusan pengadilan sendiri ada yang disebut sebagai cerai gugat. Disinilah letak perbedaannya. Bahkan ada perkawinan yang putus karena li'an, khuluk, fasikh dan sebagainya. Putusan pengadilan ini akan ada berbagai macam produknya. Pada penyebab perceraian, pengadilan memberikan legal formal, yaitu pemberian surat sah atas permohonan talak dari suami. Surat talak tersebut diberikan dengan mengacu pada alasan-alasan sebagaimana diatur dalam Pasal 39 ayat 2, dimana salah satu pihak melanggar hak dan kewajiban. Sehingga, walaupun surat talak tersebut sah secara hukum, namun tidak ada kata kesepakatan diantara dua pihak untuk bercerai.

\section{Pertimbangan Hakim Pengadilan Neg- eri Marabahan dalam Perkara Nomor: 03/Pdt.G./2011/PN Mrb.}

Data perkara perdata tertanggal 09 Mei Tahun 2011 yang terdaftar di Kepaniteraan Pengadilan Negeri Marabahan dalam register perkara Nomor: 03/Pdt.G./2011/PN Mrb. Yang pada pokoknya sebagai berikut:

1. Bahwa Penggugat telah telah melangsungkan perkawinan dengan Tergugat pada tanggal 17 Juni 1993, tercatat di Kantor Catatan Sipil Pemerintah Kabupaten Dati II Barito Selatan, sesuai Kutipan Akta Perkawinan No. 447/87/ CSK/1993.

2. Bahwa Penggugat dan Tergugat dalam ikatan perkawinan menurut agama Katolik sejak 17 Juni 1993, yang dikuatkan sesuai Surat Kawin (Testimonium Matrimoni).

3. Bahwa dari perkawinan Penggugat dan Tergugat telah lahir 3 (tiga) orang anak.

4. Bahwa semula Penggugat dan Tergugat berkumpul dalam satu rumah tangga selama kurang lebih 13 (tiga belas) tahun, mulai pada tahun1993 sampai dengan 2006 dan sejak akhir tahun 2006 antara Penggugat dan Tergugat sudah tidak rukun lagi, mengalami pertengkaran yang secara terus menerus bermula dari kesalahpahaman dan miss komunikasi.

5. Bahwa Tergugat sering tidak percaya atas pekerjaan Penggugat dan mempertanyakan pekerjaan Penggugat pada atasannya, yang puncaknya pada tanggal 7 Desember 2010 Tergugat memukul 
Penggugat.

6. Bahwa Penggugat telah menghimbau Tergugat untuk memperbaiki dirinya dengan meminta nasihat tokoh rohaniawan dan keluarga Penggugat.

7. Bahwa kerukunan dalam rumah tangga antara Penggugat dan Tergugat sudah tidak dapat dibina dengan baik, sehingga untuk mencapai rumah tangga yang tenteram dan bahagia sudah tidak dapat dipertahankan lagi dan tidak ada lagi harapan untuk hidup rukun dalam rumah tangga, karena: Tidak ada saling percaya antara suami-isteri tentang pekerjaan;

Analisis Terhadap Pertimbangan Pengadilan Tinggi Kalimantan Selatan dalam Putusan Nomor: 05/PDT./2012./ PT.BJM

Bersifat keperdataan meskipun asas indissolubility ini sudah tersirat pada asas monogami. Penulis menginginkan asas indissolubility ketentuan agama jadi pertimbangan Pengadilan Negeri selain itu hendak Pengadilan Negeri mempertimbangkan kembali Putusan perceraian dengan adanya pertimbangan Yurisprudensi Mahkamah Agung Nomor. Reg. 1400 K/Pdt/1986 tertanggal 20 Januari 1989 yang berbunyi: "Undang-undang Nomor 1 tahun 1974 tentang perkawinan menganut asas bahwa perkawinan adalah sah apabila dilakukan menurut hukum masing-masing agamanya dan kepercayaannya dan itu merupakan salah satu perwujudan dari pancasila sebagai Filsafah Negara. Perkawinan tidak lagi dilihat hanya dengan hubungan perdata, sebab perkawinan mempunyai hubungan erat sekali dengan agama/kerohanian, sehingga tidak ada perkawinan diluar hukum masingmasing agamanya dan kepercayaannya. Artinya Tergugat/Pembanding/Pemohon Kasasi dan Penggugat/Terbanding/Termohon Kasasi dalam perkara ini tetap terikat pada hukum Agama Katolik".

Analisis Terhadap Putusan Pengadilan Negeri Marabahan dalam Perkara Nomor:03/Pdt.G./2011/PN.Mrb.

Berdasarkan dari alur Perkara diatas dari segala pertimbangan terhadap petitum maka gugatan Penggugat dikabulkan seluruhnya, mengingat dan memperhatikan ketentuan perundang-undangan yang berkaitan dengan perkara ini.

Putusan perceraian Hakim menggunakan dasar pertimbangan bahwa antara suami istri terus menerus terjadi perselisihan atau pertengkaran dan tidak ada harapan hidup rukun kembali dalam rumah tangga (UndangUndang Perkawinan juncto Peraturan Pemerintah Nomor 9 Tahun 1975).

Berdasar wawancara dengan umat katolik pada hari Minggu tanggal 10 Juni 2018, Bapak Yohanes Radirusmansyah,mengatakan bahwa Hakim tidak menggunakan ketentuan Hukum Gereja Katolik dalam pertimbangan putusan perceraian meskipun menurut hukum kanonik tidak mengenal adanya istilah perceraian. Dengan adanya percerian maka kedudukan hukum suami istri tersebut masih sepasang suami-istri yang sah secara hukum gereja Katolik. Meskipun secara Hukum Nasional perceraiannya itu sah dan statusnya menjadi duda dan janda.

Hasil wawancara pada hari Minggu tertanggal 8 Juli 2018 dengan salah satu tokoh umat Katolik Gereja Katedral Banjarmasin Bapak Wanto A. Salan, mengatakan "Dalam hukum gereja tidak dikenal istilah perceraian "tidak dapat diputus oleh kuasa manusiawi mana pun" demikian Kitab Hukum Kanonik menegaskan Kutipan kata pada Kanon 1141. 


\section{PENUTUP}

\section{Kesimpulan}

Bahwa Eksistensi Asas Indissolubility Hukum Kanonik dan Hukum Perkawinan Indonesia Terhadap Putusan Pengadilan Yang Memutus Perkawinan Katolik: Pengadilan tidak memaknai ketentuan hukum agama Katolik khususnya asas Indissolubility, Bahwa Majelis Hakim Pengadilan Negeri Marabahan dalam memeriksa dan mengadili serta mempertimbangkan perkara ini dengan memutus cerai ikatan perkawinan ratum et consummatum yang memiliki asas Indissolubility absoluta (tidak dapat diputuskan atas kuasa manusia manapun kecuali oleh kematian) baik secara intrinsik (atas kehendak dan keinginan pasangan sendiri) maupun secara ekstrinsik (oleh kuasa Gereja yang berwenang). Pertimbangan hakim dalam putusan pengadilan nomor 03/Pdt.G/2011/PN.Mrb. telah sesuai dengan ketentuan Undang-Undang Nomor 1 Tahun 1974 tentang Perkawinan namun tidak sesuai dengan ketentuan Kitab Hukum Kanonik. Gereja Katolik yang tidak mengakui efektifitas putusan cerai dari pengadilan sipil, artinya sekalipun secara de facto pasangan Katolik tersebut sudah cerai melalui putusan pengadilan sipil, mereka masih terikat oleh ikatan perkawinan gerejawi.

Bahwa Kedudukan Hukum Suami-Isteri Yang Beragama Katolik Setelah Putusan Pengadilan Akibat Perceraian: kedua belah pihak tersebut masih sepasang suami-istri yang sah secara agama katolik meskipun sudah tidak sah secara putusan pengadilan.Karena tidak dikenal istilah perceraian yang "tidak dapat diputus oleh kuasa manusiawi mana pun" demikian Kitab Hukum Kanonik menegaskan Kutipan kata pada Kanon 114.

\section{Saran}

Hendaknya Hukum Nasional Pengadi- lan Negeri dalam memutus permohonan perceraian mempertimbangkan kembali ketentuan hukum agama khususnya agama katolik yang mempunyaiasas Indissolubility yang tersirat pada Undang-undang Nasional Nomor 1 Tahun 1974 Tentang Perkawinan yaitu pada asas monogam sehingga eksistensi kedua asas tersebut tidak terjadi inkonsistensi.

Bagi Gereja hendaknyamengenalkan dan memasukan pendidikan Hukum Kanonik pada kurikulum pendidikan agama khususnya agama katolik sehingga sejak usia dini sadar akan ketentuan agama terlebihnya hukum perkawinan dalam hal mengantisipasi perceraian.

\section{BIBLIOGRAFI}

Hasbullah. 1981. Kumpulan Lengkap Undang-Undang dan Peraturan Perkawinan-Indonesia. Jakarta Pusat: Penerbit Djambatan

Marzuki, Peter Mahmud. 2005. Penelitian Hukum. Jakarta: Kencana

Paulus II, Paus Yohanes, TT. Kitab Hukum Kanonik. Jakarta: Penerbit Sekretariat KWI

Robertus, Rubiyatmako. 2011. Perkawinan Katolik Menurut Kitab Hukum Kanonik. Yogyakarta, diakses tanggal 7 Juli 2018

\section{Peraturan Perundang-undangan}

Kitab Undang-undang Hukum Perdata

Undang-Undang Nomor 1 Tahun 1974 Tentang Perkawinan

Putusan Pengadilan Tinggi Kalimantan Selatan Nomor 05/Pdt./2012/PT.Bjm

Putusan Pengadilan Negeri Marabahan Nomor 03/Pdt.G/2011/PN.Mrb. 